MARTYNA ŻELAZKOWSKA

Wydział Nauk Pedagogicznych

Uniwersytet Kardynała Stefana Wyszyńskiego

Warszawa
Forum Pedagogiczne 2016/1

Wpłynęło: 30.12.2015

Zatwierdzono do druku: 14.03.2016

\title{
WYBRANE METODY TERAPII W PROCESIE LECZENIA DZIECKA PRZEWLEKLE CHOREGO
}

Streszczenie: Przedmiotem rozważań niniejszego opracowania jest przedstawienie wybranych metod terapeutycznych w procesie leczenia dziecka przewlekle chorego. W artykule wskazano też perspektywę pedagogiki terapeutycznej (leczniczej). Choroba przewlekła jest przykrym, obciążającym zdarzeniem w życiu człowieka. Jest zaburzeniem wielopłaszczyznowym, ponieważ powoduje trudności w funkcjonowaniu na wielu poziomach: fizycznym, społecznym, emocjonalnym, poznawczym. Pedagogika terapeutyczna zapewnia jednostce realizację podstawowych potrzeb psychospołecznych i biologicznych.

Słowa kluczowe: choroba przewlekła, dziecko, terapia, pedagogika terapeutyczna

\section{Wprowadzenie}

Każda choroba jest przykrym doświadczeniem w życiu człowieka. Jest zjawiskiem negatywnym, powodującym zaburzenia sprawności organizmu zarówno w aspekcie biologicznym, jak też psychicznym i społecznym. Choroba przewlekła to zaburzenie trwałe, które spowodowane jest przez nieodwracalne zmiany patologiczne. Wymaga specjalistycznego postępowania rehabilitacyjnego, długotrwałego leczenia, nadzoru, stałej obserwacji i opieki. Do chorób przewlekłych należy zaliczyć niektóre zaburzenia czynności układu nerwowego, nowotwory, liczne choroby z grupy zaburzeń psychicznych, wady genetyczne, niektóre zaburzenia czynności gruczołów wydzielania zewnętrznego, liczne choroby z grupy zaburzeń czynności układu krążenia, układu oddechowego czy układu moczowego.

Choroba przewlekła jest przykrym, obciążającym zdarzeniem w życiu każdego człowieka i jego rodziny. Może pojawić się w wieku dziecięcym, młodzieńczym lub dorosłym, i często towarzyszy człowiekowi nawet całe życie. Osoby przewlekle chore muszą liczyć się z koniecznością długotrwałego pobytu w szpitalu, a także nastawić się na długi, żmudny i uciążliwy sposób leczenia. Wszystko to łączy się 
$\mathrm{z}$ rozłąką z bliskimi, co powoduje u chorych pogorszenie samopoczucia, cierpienie psychiczne i brak wiary w lepszą przyszłość.

Choroba pojawia się nagle. Jest trudna do zaakceptowania przez samego chorego, jak też jego najbliższych. Wprowadza chaos, zamieszanie i przykre emocje, takie jak: lęk, niepewność, niepokój, strach. Zaburza porządek w funkcjonowaniu rodziny. Uzależnia chorego od otoczenia, bo zabiera mu niezależność i autonomię, a są to jedne z podstawowych potrzeb człowieka. Wprowadza wiele ograniczeń - nakazów i zakazów - dotyczących między innymi swobodnego poruszania się, możliwości wyjazdu, kontaktu z rówieśnikami i bliskimi, uczęszczania do szkoły, na zajęcia rozwijające zainteresowania i talenty dziecka, zmusza do skrupulatnej obserwacji swojego organizmu i ciągłego podporządkowywania się chorobie.

Dziecko dotknięte chorobą przewlekłą jest pacjentem szczególnym. Znajduje się w okresie wszechstronnego rozwoju, który w przebiegu choroby przewlekłej bardzo często ulega zaburzeniu. W związku z tym konieczne wydaje się podjęcie wielopłaszczyznowych oddziaływań w celu zmniejszenia prawdopodobieństwa wystąpienia negatywnych następstw związanych z samą chorobą, jak również działań wspierających rozwój takich dzieci.

W procesie ich leczenia wykorzystywanych jest wiele metod i technik, które wpływają na poprawę jakości życia. Istotne jest zapewnienie tym osobom warunków do samorealizacji, poczucia bezpieczeństwa oraz wsparcia terapeutycznego, którego głównym celem będzie obniżenie lęku.

Ważne miejsce w procesie leczenia dzieci przewlekle chorych odgrywa również pedagogika terapeutyczna, w literaturze często nazywana pedagogiką leczniczą. Głównym jej celem jest zapewnienie dzieciom chorym i niesprawnym ruchowo nieprzerwanej realizacji obowiązku szkolnego przy uwzględnieniu możliwości wysiłkowych, czyli specjalnych potrzeb edukacyjnych. Pedagogika lecznicza chroni jednostki przed ujemnymi skutkami psychicznymi spowodowanymi długotrwałymi pobytami w zakładach leczniczych oraz organizuje przebieg rewalidacji i rehabilitacji.

\section{Pedagogika terapeutyczna osób przewlekle chorych}

Pedagogika terapeutyczna jest nauką szczegółową pedagogiki specjalnej. Jej podstawy terapeutyczne stworzyła w latach 50. XX wieku Janina Doroszewska, koncentrując swoje zainteresowania naukowe wokół zagadnień dotyczących wychowania w zakładach leczniczych zarówno dzieci przewlekle chorych, jak i z uszkodzonym narządem ruchu (Maciarz 1998).

Przyglądając się historii epidemiologii chorób dziecięcych, zauważyć można w tym obszarze znaczące zmiany, które wpłynęły również na reorganizację procesu rehabilitacji przewlekle chorych. W pierwszych latach po wojnie największy odsetek stanowiły dzieci chore na gruźlicę i reumatyzm. W latach 50. doszło do epidemii choroby Heinego-Medina, w wyniku której wiele dzieci dotkniętych 
zostało dysfunkcjami narządu ruchu. Z kolei raporty z badań bilansowych przeprowadzonych przez Instytut Badań Pedagogicznych w latach 7o. i 80. ukazują, że najwięcej dzieci cierpiało z powodu chorób związanych z uszkodzeniem ośrodkowego układu nerwowego, chorób alergicznych, narządu ruchu i układu krążenia. Obecnie zauważa się również wzrost zachorowalności na nowotwory oraz zaburzenia psychiczne dzieci i młodzieży.

Choroba powoduje nie tylko zaburzenia czynności biologicznych organizmu, ale również szereg niekorzystnych zmian w życiu psychicznym. Szczególnie narażone są na nie dzieci, które nie posiadają jeszcze odpowiednich mechanizmów radzenia sobie w sytuacjach trudnych. Jedną z pierwszych koncepcji psychologicznych wyjaśniających wpływ choroby na życie psychiczne dziecka stworzyła Janina Doroszewska. Uważała ona, że każda choroba powoduje kształtowanie się tzw. swoistych obrazów psychicznych. Powodują one znaczące zmiany w osobowości dziecka. Ważną rolę w wytwarzaniu swoistych obrazów psychicznych związanych $\mathrm{z}$ daną chorobą przypisywała cechom konkretnego układu nerwowego. Poglądy Doroszewskiej wywarły znaczny wpływ na badania prowadzone na przełomie lat 6o. i 70. Badacze aktywnie poszukiwali zależności między rodzajem i stopniem nasilenia choroby a cechami psychicznymi dzieci. W swoich rozważaniach byli zgodni co do wpływu choroby na rozwój psychiczny człowieka. Choroba bowiem utożsamiana jest ze stresem, jest źródłem frustracji i często powoduje deprywację potrzeb człowieka, co w konsekwencji wpływa na jego funkcjonowanie i relacje z otoczeniem. Rodzaj zmian w zachowaniu dziecka zależy od siły obciążenia, jakie stwarza choroba, jak również od właściwości jego osobowości, w tym także od ukształtowanych u dziecka nawyków reagowania na trudności (Obuchowska, Krawczyński 1991).

Pedagogika terapeutyczna stanowi ważny element w procesie leczenia osób przewlekle chorych, niepełnosprawnych ruchowo, które na skutek swojej niedyspozycji są często wyizolowane z naturalnego środowiska. Do jej głównych celów i zadań zaliczyć można: ochronę jednostki przed ujemnymi skutkami psychicznymi, które związane są z długotrwałym pobytem w zakładach leczniczych, mobilizowanie chorego do polepszenia własnej sytuacji życiowej, współdziałanie w zapewnieniu mu możliwości realizowania podstawowych potrzeb psychospołecznych i biologicznych, organizowanie procesu rewalidacji i rehabilitacji, jak również udzielenie wsparcia i pomocy po opuszczeniu zakładu leczniczego. Ważne jest również zwrócenie uwagi na przemiany, jakie dokonały się w organizowaniu rehabilitacji dzieci przewlekle chorych. Spowodowały one rozszerzenie zainteresowań pedagogiki terapeutycznej o ich sytuację w środowisku rodzinnym, szkole i społecznościach dzieci zdrowych (Maciarz 1998). Zajęto się właściwą organizacją zarówno procesu opiekuńczo-wychowawczego, jak też edukacyjnego. Większość rodziców dzieci przewlekle chorych przyjmuje bowiem postawę tzw. aktywnej akceptacji chorego dziecka, która charakteryzuje się przyjmowaniem choroby jako zdarzenia losowego, wobec którego rodzina mobilizuje się zarówno fizycznie, jak 
i psychicznie. Skupienie się tylko na zdrowiu somatycznym dzieci wiąże się jednak często $\mathrm{z}$ zaniedbywaniem ich potrzeb psychicznych i społecznych. Koncentracja na biologicznych aspektach choroby implikuje nadopiekuńczość rodziców, co w konsekwencji powoduje utrzymanie silnej, symbiotycznej więzi z dzieckiem i niedocenianie potrzeby usamodzielniania go (Maciarz 1998, s. 224). Również w szkole nauczyciele często stosują wobec dziecka chorego tzw. taryfę ulgową. Nie stawiają mu wymagań dydaktycznych dostosowanych do jego indywidualnych możliwości, samopoczucia i zdolności do wysiłku w danym okresie choroby. Częstym problemem w szkole jest także stosunek rówieśników do chorego dziecka. Może być ono narażone na izolację lub odrzucenie, jeśli wobec zdrowych dzieci zaniecha się oddziaływań wychowawczych, kształtujących postawy życzliwości i zrozumienia wobec chorego kolegi.

Zabezpieczenie choremu dziecku należytej opieki leczniczej i wychowawczej nie jest zadaniem prostym. Złożoność uwarunkowań sprawia, że otoczenie nie zawsze potrafi właściwie się $\mathrm{z}$ nim porozumieć i podjąć odpowiednie, wspólne działania. Jednak różne ośrodki rehabilitacji, stowarzyszenia społeczne i poradnie specjalistyczne wyposażają rodziców, nauczycieli i osoby przebywające z chorym dzieckiem w odpowiednią wiedzę i umiejętności, wzmacniają ich psychicznie, co czyni rodzinę i szkołę bardziej kompetentnymi do tworzenia dziecku przewlekle choremu właściwego środowiska terapeutycznego.

\section{Wybrane problemy dziecka przewlekle chorego}

Wyniki badań ankietowych nad zdrowiem i zachowaniami zdrowotnymi młodzieży szkolnej dowodzą, że przewlekle chorzy uczniowie znacznie gorzej oceniają swoje zdrowie, wygląd, zadowolenie z życia i samopoczucie niż ich rówieśnicy. Gorsze samopoczucie, występowanie przykrych dolegliwości fizycznych związanych $\mathrm{z}$ chorobą oraz negatywnych stanów emocjonalnych wpływają na to, że nie wierzą oni w swoje zdolności do uczenia się i tworzenia pozytywnych relacji z innymi ludźmi. Również wyniki sprawdzianów, testów, ocen wskazują, że osiągnięcia chorych uczniów są poniżej przeciętnych. Jeśli przyjrzeć się bliżej badaniom i obserwacjom dzieci chorych w relacji z rówieśnikami, to pokazują one, że prawie dwukrotnie częściej są one ofiarami przemocy w szkole, częściej też mają poczucie, że inni nie akceptują ich takimi, jakimi są (Woynarowska 2010).

„Do najważniejszych następstw ograniczających szanse rozwoju chorego dziecka należą: lęk, koncentracja na wartościach podstawowych, koncentracja na tu i teraz, poczucie nieuchronności i bezsilności, utrata nadziei, perspektywy życiowej, poczucie ubezwłasnowolnienia i utraty wolności, obniżenie poczucia własnej wartości, poczucie wstydu, bycia innym, deprywacja potrzeb emocjonalnych, bierność" (Góralczyk 1996, s. 31). Badania empiryczne pokazują, że nie ma jednego specyficznego wzorca osobowości dziecka przewlekle chorego. Można jednak dostrzec u niego pewne charakterystyczne cechy, rodzaje zachowań i zaburzeń 
emocjonalnych, które niewątpliwie wiążą się z chorobą, sposobami leczenia, rokowaniem. Zaobserwowano wyższy poziom introwersji, neurotyzmu i cech schizoidalnych, przejawiający się skłonnością do zamykania się w sobie, trudnościami w nawiązywaniu i podtrzymywaniu satysfakcjonującego kontaktu $\mathrm{z}$ rówieśnikami, trzymaniem się na uboczu, nieśmiałością, niechęcią do współzawodnictwa, pasywnością, a także nieumiejętnością odprężenia się i zrelaksowania. Dominującym uczuciem jest lęk oraz stałe poczucie winy i krzywdy. Dzieci przewlekle chore mają zaniżoną samoocenę, która wyraźnie wpływa na ich rozwój społeczny, emocjonalny i poznawczy. Oceniają siebie krytycznie. W stosunku do innych ludzi, rówieśników trzymają się na dystans, nie wchodzą w głębsze relacje. Świat z kolei oceniają jako nieprzewidywalny, źle urządzony i zagrażający. Jest to powodem znacznie częstszego występowania u nich symptomów psychiatrycznych, które ujawniają się w reakcjach depresyjnych, lękowych czy zespołach astenicznych.

„Psychika dziecka jest wrażliwa i bardziej podatna na urazy niż psychika dorosłego, co powoduje, że nie posiada ono umiejętności radzenia sobie w trudnych sytuacjach" (Jachimczak 2011, s. 37). W czasie zmiany leków dziecko doświadcza często szeregu dolegliwości, które niewątpliwie wpływają na jego funkcjonowanie psychofizyczne, takich jak: senność, apatyczność, zaburzenia koncentracji, nadwrażliwość, nadpobudliwość psychoruchowa. Dzieci chore na ogół znacznie wolniej wykonują wiele prac, szybciej się męczą, co sprawia, że uważają siebie za gorszych towarzyszy zabaw czy współwykonawców prac zespołowych. Wpływa to na ich poczucie wartości i znacznie obniża samoocenę. Niechęć do współzawodnictwa czy rozwijania wspólnych zainteresowań może powodować izolację chorego dziecka przez kolegów, a to z kolei prowadzi do niezaspokojenia podstawowej potrzeby człowieka - przynależności do grupy. Częste absencje w szkole powodują trudności w zaspokojeniu potrzeby kontaktów społecznych. Konsekwencją tego mogą być trudności w rozumieniu reguł i norm, które obowiązują w grupie rówieśniczej.

Kolejnym problemem, z którym może spotkać się dziecko, jest negatywny stosunek rówieśników do jego choroby. Z jednej strony, brak wiedzy, niezrozumienie kolegów mogą sprawić, że zacznie postrzegać siebie i swoją chorobę w kategoriach piętna, a co gorsza generalizować ją na całokształt swojej osobowości. Powoduje to tworzenie się kompleksów, obniżenie poczucia własnej wartości, co w ostateczności może doprowadzić do zamknięcia się dziecka w sobie. Z drugiej zaś strony, może ono stanąć przed koniecznością tłumaczenia kolegom istoty swojej choroby, co również w wielu przypadkach jest dla chorego stresującym, trudnym doświadczeniem. Łączy się bowiem z lękiem przed niezrozumieniem i odrzuceniem.

Poważną trudnością i niewątpliwie ogromnym problemem dla dziecka przewlekle chorego jest uzależnienie od otoczenia i potrzeba częstej pomocy. Wymaga ono szczególnej uwagi ze strony nauczycieli, psychologa, lekarzy, a niekiedy również systematycznego (w przypadku podawania leków i robienia zabiegów) oraz zorganizowanego wsparcia różnych instytucji. To nasila w chorym dziecku bezsilność i bezradność. Umacnia poczucie braku wpływu na zdarzenia i nieradzenia sobie 
samemu. Dodatkowy element stanowi stała konieczność obserwowania i kontrolowania objawów choroby i samopoczucia. Wymaga to od dziecka skupienia uwagi na sobie i otoczeniu pod kątem zapewnienia sobie bezpieczeństwa. Chore dzieci znaczniej szybciej muszą nauczyć się odpowiedzialności za swój stan zdrowia niż ich zdrowi koledzy (Góralczyk 2009).

Niewątpliwie duży problem stanowi dla dziecka przewlekle chorego ograniczenie jego samodzielności i uzależnienie od otoczenia. Jest to dla rozwoju sfery motywacyjnej i wolicjonalno-dążeniowej ogromna trudność. Dziecko będące w sytuacji codziennego uzależnienia od innych staje się bowiem bierne, mało zaradne, nastawione roszczeniowo. Proces usamodzielniania się, kształtowania woli, motywacji do działania oraz możliwości pokonywania trudności i podejmowania decyzji ulegają opóźnieniu.

Ważnym aspektem, na który należałoby zwrócić uwagę, rozpatrując potencjalne trudności dziecka przewlekle chorego w szkole, jest jego rozwój poznawczy i związana z nim potrzeba aktywności eksploracyjnej. Długotrwałe leczenie powoduje ograniczenie możliwości uczenia się i osiągania satysfakcjonujących wyników w nauce. Uczeń wielokrotnie ma złe samopoczucie, odczuwa osłabienie. Choroba obniża jego wydolność fizyczną i umysłową. Nieobecności w szkole powodują zaległości w realizacji programu dydaktycznego, których wyrównanie często jest bardzo trudne. Zahamowaniu ulega aktywność dziecka - zarówno ta poznawcza, intelektualna, jak też fizyczna. Niektóre choroby przewlekłe, takie jak astma czy wady serca, nie pozwalają na duży wysiłek. Z kolei stany gorszego samopoczucia oraz przyjmowanie niektórych leków wpływają na pogorszenie procesów poznawczych: osłabienie pamięci, uwagi, koncentracji.

Rozpatrując trudności dzieci przewlekle chorych, należy także przyjrzeć się aspektowi motywacyjnemu, który dotyczy głównie sfery zainteresowań i rozwijania talentów. U znacznej części tego typu dzieci zauważa się niską wewnętrzną motywację do nauki. Spowodowane jest to brakiem nadziei na realizację marzeń w przyszłości. Chory nie wierzy w to, że jest w stanie mimo choroby osiągnąć swoje bliższe czy dalsze cele. Jego działania skoncentrowane są na tu i teraz. Brak takiej wewnętrznej motywacji skutkuje często zrezygnowaniem, znacznie obniżonym nastrojem, apatią i izolacją. Pojawia się lęk przed śmiercią lub krótszym trwaniem życia.

\section{Metody terapii w procesie leczenia dziecka przewlekle chorego}

Praca z dzieckiem chorym wymaga stałych poszukiwań różnych metod i form terapii, które będą dostosowane do jego potrzeb, oczekiwań i możliwości. Należy dobrać je tak, by wspomagały rozwój jednostki, zachęcały do pokonywania trudności i umacniały wiarę we własne możliwości. Wszystkie oddziaływania dydaktyczno-wychowawcze powinny być dobrane indywidualnie, dokładnie opracowane, celowe i zgodne z potrzebami dziecka. Znaczenie mają także cechy osoby pomagającej 
w pokonywaniu trudności. Oczekuje się, aby „terapeuta/nauczyciel, jak również rodzic był cierpliwy, ciepły, wyrozumiały, współczujący, serdeczny, mobilizujący i przede wszystkim, swoją postawą, zachęcający dziecko do nauki, wysiłku i poszukiwania swoich pasji, priorytetów i wartości” (Góralczyk 2009).

Zadania terapeutyczno-wychowawcze są zadaniami ogólnopedagogicznymi, umożliwiającymi choremu dziecku taki rozwój na poziomie umysłowym, uczuciowym i ruchowym, na jakim się ono znajduje, oraz doprowadzenie do takiego etapu rozwoju, jaki jest dla dziecka pożądany lub chociaż dostępny (Doroszewska 1963).

Rozważania niniejszego rozdziału będą związane z opisem niektórych metod i technik terapeutycznych, które wykorzystywane są w pracy z dzieckiem przewlekle chorym.

Istotnym jej elementem jest kontakt terapeutyczny. Nie tylko redukuje lęki, zmniejsza negatywne napięcia i przygnębienia dziecka, lecz przede wszystkim mobilizuje do współdziałania $\mathrm{z}$ terapeutą $\mathrm{w}$ procesie leczenia i rehabilitacji oraz nauczycielem $\mathrm{w}$ procesie rewalidacji. Terapeuta $\mathrm{w}$ pracy $\mathrm{z}$ dzieckiem za pomocą wszelkich metod dąży do wyeliminowania niektórych jego właściwości psychicznych, np. negatywnych emocji czy niskiej samooceny.

Niezbędną formą pracy terapeutyczno-wychowawczej jest zabawa. Pobudza ona do wspólnego, wartościowego przeżywania świata, umożliwia wzajemne kontakty poprzez ruch, taniec, zakładanie masek, śpiew, rozmowy. Zabawa pozwala rozwinąć w dziecku zachowania prospołeczne, uwrażliwia na innego człowieka. Uczy uważnego słuchania i patrzenia na siebie z różnych perspektyw. Stanowi okazję do projekcji własnych uczuć, napięć, niepokojów, konfliktów i stresów. Rozwija uwagę i spostrzegawczość, umożliwia dziecku wzrost wiary w siebie, zwiększa poczucie własnej wartości. Gry i zabawy uczą zasad zdrowej rywalizacji i niepoddawania się przeciwnościom. Podczas gier dzieci ustalają wspólne reguły, przez co uczą się współdziałania i radości z pracy prowadzącej do wspólnych efektów. Są one zawsze źródłem spokoju i uśmiechu. Umiejętność dobrania odpowiednich zabaw i gier dydaktycznych zaspokaja u chorego dziecka potrzebę pozytywnych kontaktów z otoczeniem, uznania społecznego, osiągnięć, pokonywania trudności, co w konsekwencji wpływa na poprawę efektów nauczania.

Techniki ekspresyjne, a wśród nich terapia przez sztukę, również odgrywają dużą rolę w procesie terapeutycznym dziecka przewlekle chorego. Pozwalają na wyrażanie uczuć bez posługiwania się słowem. Poprzez ekspresję dziecko rozładowuje napięcie, przeżywa radość z tworzenia, uświadamia sobie własne możliwości twórcze, rozwija umysł, integruje emocje z działaniami.

Kolejną formą jest ekspresja plastyczna, która rozwija wrażliwość wzrokową i wyobraźnię twórczą. Wyzwala motywację dziecka, kształtuje zdolność do wytrwałego działania, redukuje lęk i napięcia.

W pracy terapeutycznej często stosuje się również techniki kukiełkowe, dramę/ pantomimę. Są one zalecane głównie dla dzieci w wieku 9-12 lat, które przejawiają problemy w kontaktach społecznych. Odgrywane przez nie sytuacje są okazją do 
rozmowy o uczuciach, emocjach, motywach działania. Wyzwalają aktywność twórczą, przełamują nieśmiałość i lęk.

Dziecko uczy się również sposobów wyrażania swoich uczuć poprzez literaturę piękną oraz bajki i baśnie. Identyfikując się z bohaterami, przeżywa ich porażki i zwycięstwa. Interioryzuje wartościowe wzorce zachowań, uczy się form zachowań społecznie aprobowanych, bogatych w treści poznawcze i uczuciowe. Literatura wzbogaca wiedzę dziecka o nowe normy, zasady i motywy postępowania. Dzięki przeżyciom bohaterów z książek stopniowo uzyskuje ono wgląd we własną osobowość. Z kolei poprzez baśń jest w stanie dostrzec uroki życia, związki pomiędzy człowiekiem a otaczającą go przyrodą. W wieku dziecięcym jesteśmy skłonni do twórczego fantazjowania i emocjonalnego przeżywania kultury symbolicznej. Świat fantastyki służy właściwemu odczytaniu aktualnych od wielu wieków przesłań, mądrości i wierzeń ludowych.

Coraz częściej w pracy terapeutycznej z dzieckiem przewlekle chorym wykorzystuje się muzykoterapię. Jest ona uznawana za jedną $\mathrm{z}$ najstarszych form oddziaływania na psychikę człowieka. Przez terapeutów traktowana jest jako metoda wspomagająca proces leczenia, służąca przede wszystkim celom terapeutyczno-wychowawczym. Punktem wyjścia jest poprawa obrazu własnej osoby, aby korzystnie wpłynąć na motywację dziecka do doskonalenia umiejętności słuchowych, koordynacji ruchowej i zdolności porozumiewania się. Zajęcia muzykoterapeutyczne dostarczają dziecku przyjemności, doznań estetycznych, a także pozwalają na ekspresję pozytywnych oraz negatywnych emocji, są formą wyrażania siebie. Marek Konopczyński twierdzi, że „muzyka to środek ułatwiający wyładowanie niezaspokojonych uczuć i popędów, dynamizujących i stymulujących, ożywiający fantazję, zaprowadzający rytm, synchronizację i ład funkcji psychofizycznych, ułatwiający ujawnienie własnego, ekspresyjnego zachowania się, wyrażanie siebie. Specyficzna rola muzyki polega na tym, iż posługuje się ona mową złożoną z semantycznych symboli brzmieniowych, komunikując treści, jakich nie są w stanie przekazać ani słowa, ani obrazy" (Konopczyński 1996). Podstawą zajęć muzykoterapeutycznych są śpiew i rytmika.

Warunki życia szpitalnego bądź dłuższy pobyt dziecka w domu ograniczają jego możliwości właściwego rozwoju psychospołecznego, powodują długotrwałe napięcie psychiczne, osłabiają odporność lub są przeszkodą w odpowiednim jej ukształtowaniu. Przeżywanie radości podczas zabaw, gier, rysowania, odgrywania ról, czytania książek, bajek, baśni jest uznawane za lekarstwo dla zmęczonego systemu nerwowego. Dlatego dobór odpowiednich metod i technik pracy z dzieckiem przewlekle chorym jest niezbędny, aby jego rozwój mógł przebiegać właściwie, aby ograniczyć mu i tak bolesne doświadczenia, które są nieodłącznym składnikiem każdej choroby przewlekłej. Powyższe rozważania dowodzą, że wspomniane metody i techniki są bardzo skutecznym lekarstwem dla psychiki młodego pacjenta. 


\section{Zakończenie}

Dzieci dotknięte chorobą przewlekłą narażone są nie tylko na ból somatyczny, który jest przejawem choroby, ale także na psychiczny. Leczenie ogranicza ich aktywność zarówno fizyczną, jak i społeczną. Zmusza do stałej koncentracji na funkcjach organizmu. Choroba silnie uzależnia dziecko od innych osób. Staje się ono w takiej sytuacji bierne, mało zaradne. W związku z powyższym wskazane jest prowadzenie zajęć, których celem będzie: uaktywnienie dziecka, zmotywowanie, redukcja napięć, wzrost samooceny i poprawa kontaktów interpersonalnych. Realizacja powyższych zadań możliwa jest tylko i wyłącznie przy uwzględnieniu zasady akceptacji chorego i jego choroby, pomocy, indywidualizacji terapii pedagogicznej i współpracy z rodziną.

Jak wynika z powyższych rozważań, terapia w procesie leczenia dziecka przewlekle chorego opiera się na różnych formach zajęć zespołowych albo indywidualnej działalności jednostki. Tworzone obszary oraz programy pracy terapeutycznej ściśle definiują nam zakres pomocy dziecku choremu. Główne działania koncentrują się bowiem na zapobieganiu pogłębianiu się niepełnosprawności oraz stymulowaniu i kierowaniu właściwym rozwojem dziecka. Terapeuta-nauczyciel dąży do usprawniania zaburzonych lub słabo rozwiniętych funkcji. Wyboru odpowiednich technik dokonuje na podstawie diagnozy zaburzeń występujących u chorego. Podstawą jest dostosowanie metod pracy do aktualnych możliwości fizycznych i psychicznych dziecka. Terapeuta-nauczyciel powinien podążać za swoim wychowankiem, nieustannie obserwować jego postępy i korygować poziom trudności wykonywanych zadań. Musi zdawać sobie sprawę z faktu, że zbyt wymagające zadania mogą zmniejszyć wiarę dziecka we własne siły, obniżyć jego poczucie wartości i zahamować proces rozwojowy. Zadania zbyt łatwe nie wykorzystają zaś w pełni potencjału dziecka i również spowolnią jego rozwój.

Oddziaływania o charakterze terapeutycznym i profilaktycznym, dotyczące sfer emocjonalnej, edukacyjnej i społecznej, mogą przyczynić się do zapobiegania zaburzeniom psychicznym spowodowanym przez zły stan zdrowia oraz do wyeliminowania ich objawów, gdy już wystąpią. „Prawidłowe zaspokojenie biologicznych potrzeb może przyczynić się do poprawy stanu zdrowia, ułatwić i wspomagać proces leczenia. Zaspokojenie potrzeb psychicznych natomiast będzie miało znaczący wpływ na prawidłowy rozwój osobowości chorego dziecka” (Janion 2000, s. 35).

\section{Bibliografia}

Doroszewska J. (1963). Nauczyciel-wychowawca w zakładzie leczniczym. Warszawa: Państwowe Zakłady Wydawnictw Szkolnych.

Góralczyk E. (1996). Choroba dziecka $w$ twoim życiu: o dzieciach ciężko i przewlekle chorych $i$ ich rodzicach. Warszawa: Centrum Metodyczne Pomocy Psychologiczno-Pedagogicznej MEN. 
Góralczyk E. (2009). Dziecko przewlekle chore. Psychologiczne aspekty funkcjonowania dziecka w szkole i przedszkolu. Informacje dla pedagogów i opiekunów. Warszawa: Centrum Metodyczne Pomocy Psychologiczno-Pedagogicznej.

Jachimczak B. (2011). Dydaktyczne i pozadydaktyczne uwarunkowania efektów nauczania indywidualnego dzieci przewlekle chorych. Kraków: Oficyna Wydawnicza Impuls.

Janion E. (2000). Zaspokajanie potrzeb psychicznych dzieci przewlekle chorych. „Problemy Opiekuńczo-Wychowawcze”, nr 1, s. 32-35.

Konopczyński M. (1996). Twórcza resocjalizacja. Wybrane metody pomocy dzieciom i młodzieży. Warszawa: MEN.

Maciarz A. (1998). Pedagogika terapeutyczna dzieci przewlekle chorych. W: Dykcik W. (red.). Pedagogika specjalna. Poznań: Wydawnictwo Naukowe Uniwersytetu im. Adama Mickiewicza w Poznaniu.

Obuchowska I., Krawczyński M. (1991). Chore dziecko. Warszawa: Nasza Księgarnia. Woynarowska B. (2010). Uczniowie z chorobami przewlekłymi. Jak wspierać ich rozwój, zdrowie i edukację. Warszawa: Wydawnictwo Naukowe PWN.

\section{SELECTED METHODS OF THERAPY IN THE TREATMENT PROCESS OF A CHRONICALLY ILL CHILD}

Abstract: The article presents some of the therapeutic methods used in the treatment of a chronically ill child. The prospect of therapeutic pedagogy is presented in the undertaken topic. Chronic disease is an unpleasant, stressful occurrence in a human life. This is a multidimensional disorder as it causes difficulties in functioning at different levels, such as physical, social, emotional and cognitive. Therapeutic pedagogy provides an individual with basic psychosocial and biological needs.

Key words: chronic disease, child, therapy, therapeutic pedagogy

Martyna Żelazkowska - doktor, asystent w Katedrze Psychopedagogiki na Wydziale Nauk Pedagogicznych UKSW. Jej główne przedmioty badań i zainteresowań naukowych to psychologia kliniczna, zdrowia i terapia oraz psychoprofilaktyka społeczna. Adres korespondencyjny: Wydział Nauk Pedagogicznych UKSW, ul. Wóycickiego 1/3, budynek 15, 01-938 Warszawa. Adres e-mail: m.zelazkowska@wp.pl. 